\title{
APPLICATION OF THE HEXAGONAL MODEL OF REGIONAL ECONOMIC DEVELOPMENT TO THE CONCEPT OF CREATIVE ECONOMY
}

\author{
Petra Kunertova, University of Zilina
}

dx.doi.org/10.18374/CBR-1-2.2

\begin{abstract}
Creative industries and overall creative economy are regarded as one of the most promising economic sectors with high potential to contribute to local and regional wealth and jobs creation. Thus, the settlement of creative industries firms is an important location, image and economic development factor for the competitiveness of a region. Creativity and culture has come to be seen as a way of jump-starting economic recovery, boosting tourism and offering new sources of employment. The ideas of several experts on creative economy led many economic development agencies to see the creative industries as a tool for regional economic revival. Creative cities and regions do better to attract talented people who can build creative centers to fuel creative economies. The paper explores the integration of the creative economy in regional economic development. It starts with explaining the concept of creative economy and its role in the regional development. The main objective of the paper is to modify the hexagonal model of regional economic development in terms of creative economy and subsequently create a modified model that will be useful in a research of the impact of creative economy on the regional development.
\end{abstract}

Keywords: Creative economy, Creative Industries, Creative City, Creative Class, Regional Economic Development 